\title{
Techniczne atrybuty oryginalnego systemu podwieszonej pasażerskiej kolejki estakadowej
}

\begin{abstract}
$W$ artykule zaprezentowano opatentowany system techniczny podwieszonej kolejki estakadowej, wyposażonej $w$ wagoniki $z$ indywidualnym napędem i sterowaniem, ze szczególnym uwzględnieniem uktadu biegowego. Mechaniczny układ zawieszenia wagonika wyposażonego w oryginalny układ biegowy umożliwia wybór trasy (z pokładu wagonika) i sterowanie (marszruty) jego ruchu w obrębie określonej sieci torów. Sieć torów transportowych (trajektorii) kolejki nie ma ruchomych (przestawnych) zwrotnic i jest pozbawiona jakichkolwiek części ruchomych.

Temat zostat zrealizowany $w$ ramach grantu rektorskiego $n r 503$ S/1160/4620 z czerwca 2006 r Politechniki Warszawskiej.
\end{abstract}

\section{Stan techniki znanych kolei estakadowych}

Systemy transportu estakadowego z wagonikami lub uchwytami ładunkowymi, (poruszającymi się nad/pod estakadą) są dość powszechnie znane i rozpowszechnione $\mathrm{w}$ wielu zastosowaniach. Wagoniki podwieszone poruszają się pod wspornikami torowymi, lecz nad poziomem terenu. Liczne odmiany podwieszanych kolejek linowych, wagonikowych oraz zaczepowych, stosowane są $\mathrm{w}$ górskich wyciagach narciarskich, w halach przemysłowego montażu produktów masowych, w magazynach i w górnictwie.

Podwieszane systemy jednotorowe pracują dwukierunkowo w transportowych układach trasy zdeterminowanej kształtami linii, lub sieci rozgałęzionej. Trasy w kształcie pętli toru sztywnego przeznaczone są do transportu jednokierunkowego. Takie trasy spotyka się w halach montażowych i w parkach rozrywki.

Systemy kolejek estakadowych podwieszanych pod sztywnymi belkami sieci rozgałęzionej są szczególnie rozpowszechnione w górnictwie. Górnicze koleje estakadowe, pracujące $\mathrm{w}$ rozgałęzionej sieci torowej podziemnych chodników transportowych wyróżniają się występowaniem rozjazdów torowych, dzięki którym wagoniki mogą być kierowane do określonego szybu lub chodnika.

Wszystkie rozgałęzione sieci estakadowych torów naziemnych oraz podziemnych, dla umożliwienia rozrządzania trasy ruchu pojazdów według założonej marszruty, w obrębie rozjazdów zawierają ruchome, przełączane zwrotnice. Zwrotnice rozjazdów wszystkich znanych sieci kolejowych, naziemnych, podziemnych i estakadowych, są przestawnymi, ruchomymi i sterowanymi częściami infrastruktury torowej.

\section{Oryginalny atrybut systemu}

Oryginalnym atrybutem prezentowanego rozwiązania jest eliminacja ruchomych części torowej infrastruktury, przestawnych rozjazdów, przy równoczesnym umożliwieniu zautomatyzowanego sterowania, z pokładu wagonika, marszruty $\mathrm{w}$ obszarze określonej sieci układu torowego (według wybranego przez pasażera punktu docelowego).

Realizacja atrybutu stała się możliwa dzięki zastosowaniu toru estakadowego w postaci dwóch szyn, ułożonych jedna nad druga, w układzie pionowym. Układ szyn wraz z podwieszonym wagonikiem pokazano na rysunku 1.

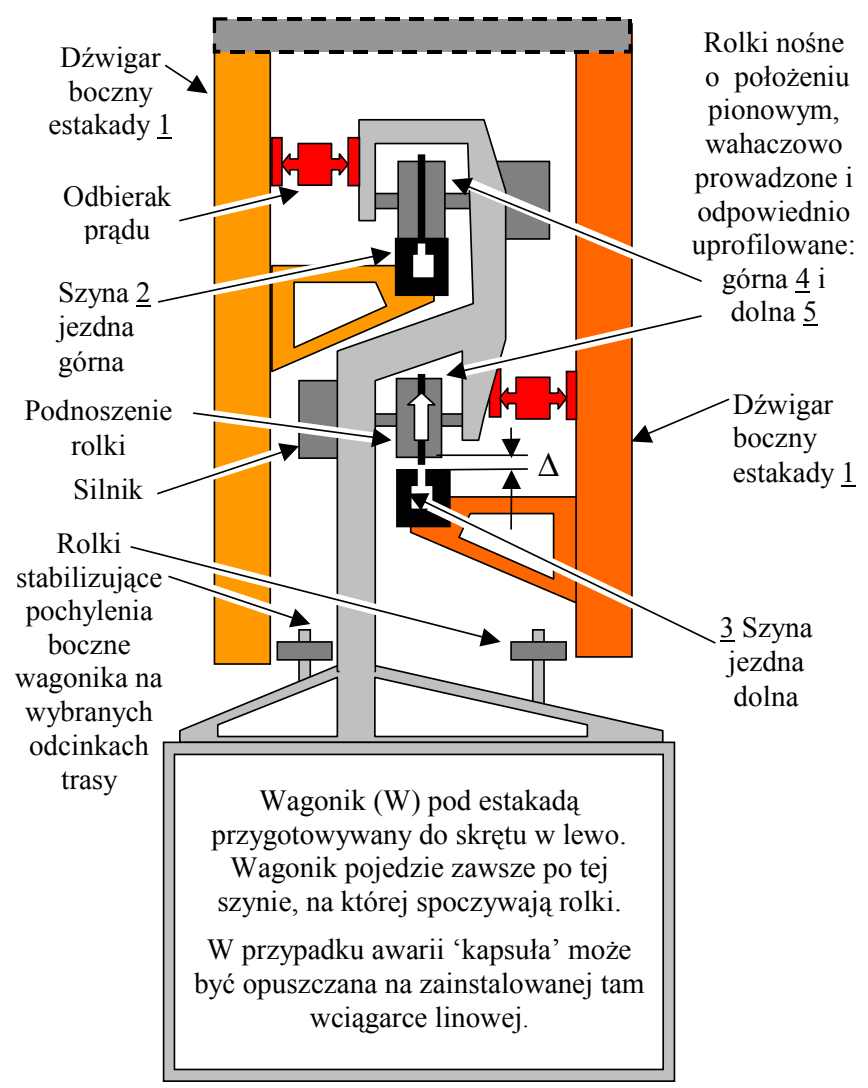

Rys.1. Wagonik podwieszony pod estakadą 
Rys. 1 przedstawia widok wagonika pod estakada belkową. Estakada 1 zawiera dwie 'nitki' (trajektorie) toru: górną 2 , skojarzoną z zaprojektowanym kierunkiem ruchu „W lewo" lub „w prawo”, oraz dolną $\underline{3}$, odpowiednio skojarzoną $\mathrm{z}$ drugim zaprojektowanym kierunkiem ruchu „w prawo” lub „w lewo”. Na rys. 1 przykładowo pokazano skojarzenie 'nitka' górna $\mathrm{w}$ lewo - dolna w prawo.

Uprofilowane rolki nośne wagonika, górne $\underline{4} \mathrm{i}$ dolne $\underline{5}$, współpracujące $\mathrm{z}$ odpowiednio uprofilowanymi szynami $\underline{2}$ i $\underline{3}$, są zarazem rolkami trakcyjnymi: napędnymi i hamującymi.

Podczas ruchu wagonika w obrębie toru prostego, a także w torowym łuku bez rozjazdów, pracują trakcyjne rolki nośne górne $\underline{4}$ lub dolne $\underline{5}$, albo nawet równocześnie zarówno rolki dolne $\underline{5}$, jak i górne $\underline{4}$.

\section{Wybór marszruty wagonika}

Docelowy punkt podróży (transportu) w obrębie znanej sieci torów (trajektorii transportowych) jest wybierany przez pasażera przyciskiem na pokładzie wagonika. Wybór trasy (marszruty) przejazdu wagonika w obrębie znanej sieci torowej jest dokonywany i sterowany automatycznie przez odpowiednio oprogramowany system komputerowy wagonika wyposażonego w układ napędowy. Sterowanie polega na unoszeniu odpowiednich rolek biegowych, dolnych lub górnych. Na rys. 2 pokazano układ stałych rozjazdów.

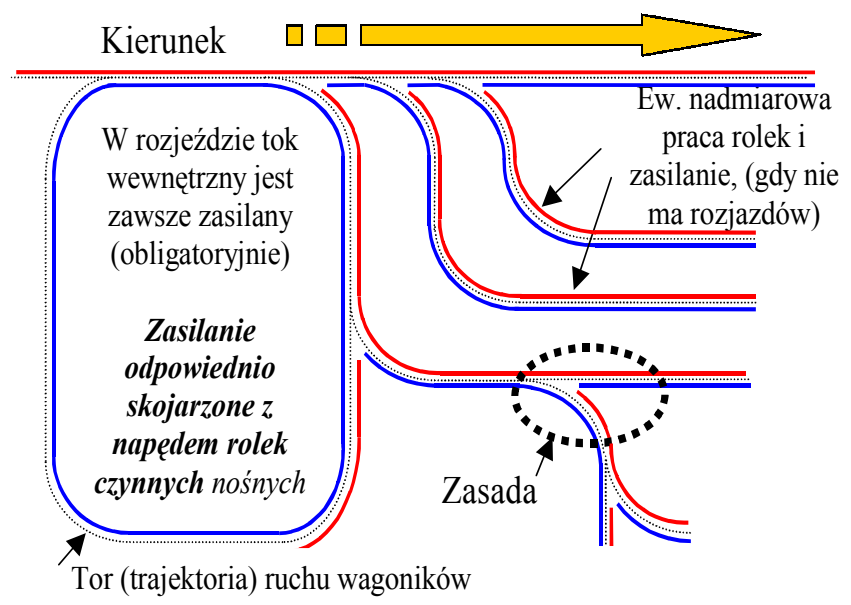

Rys.2. Ilustracja układu stałych rozjazdów i zasady skojarzenia szyn biegowych z szynami zasilającymi wagonik w energię elektryczną

Nie istnieją żadne formalne ograniczenia odnośnie do rozbudowy estakadowej sieci torowej w układzie kratownicy lub pajęczyny.

\section{Mechaniczny uklad wykonawczy wyboru trasy \\ Przykładowy schemat wykonawczego układu me- chanicznego unoszenia rolek trakcyjnych wagonika, dolnych $\underline{5}$ lub górnych $\underline{4}$, przedstawiono na rys. 3 .}

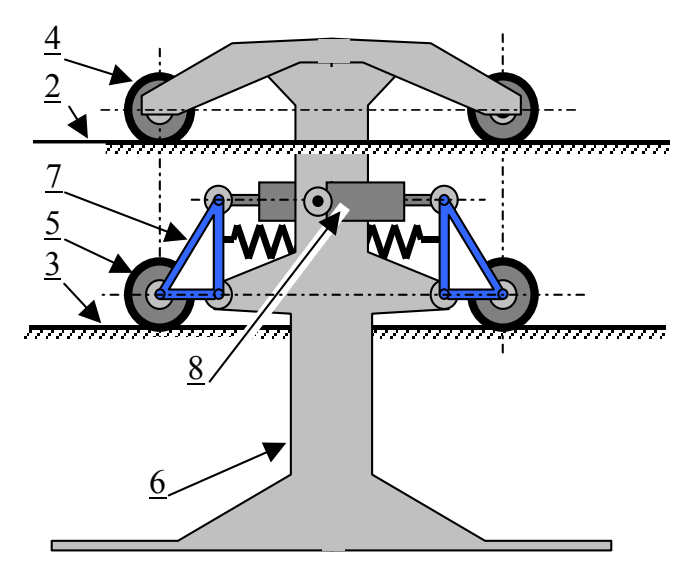

Rys.3. Schemat wykonawczego układu mechanicznego unoszenia rolek trakcyjnych wagonika

Do ramy nośnej $\underline{6}$ wagonika są obrotowo przyłączone wahacze $\underline{7}$, obracane za pomocą siłowników $\underline{8}$. Przed rozjazdem w lewo zostaną uniesione rolki $\underline{5}$, zaś przed rozjazdem w prawo, - rolki 4 . Sterowanie siłowników dwustanowe: a) olej wtłoczony pod ciśnieniem - uniesione rolki górne, b) gdy olej z siłownika swobodnie wypłynie, pozostają uniesione rolki dolne.

Zasadę unoszenia rolek dolnych przy skręcie w lewo i górnych przy skręcie w prawo, przedstawiono na rysunku 4.
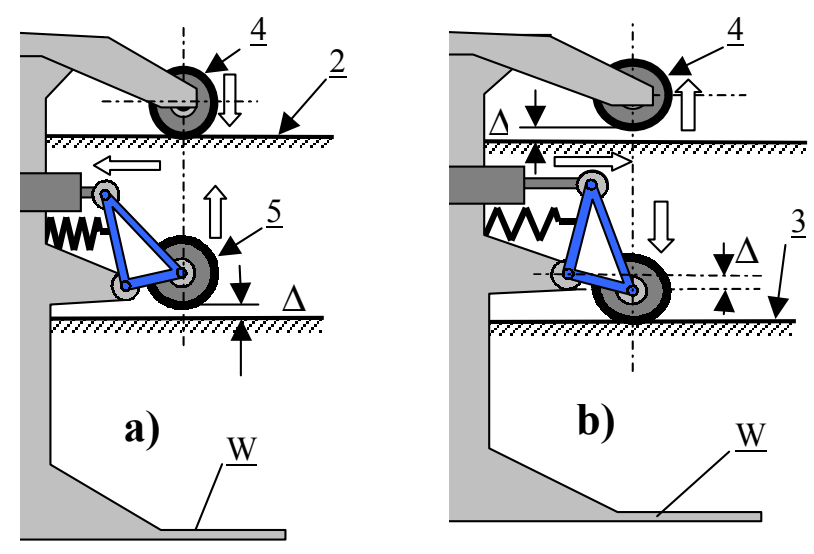

Rys.4. Zasada unoszenia rolek a) dolnych i b) górnych

Wagonik podwieszonej kolejki estakadowej najkorzystniej biegnie tylko po jednej szynie jezdnej $\underline{2}$ lub $\underline{3}$. Zmiana szyny biegowej według wybranej marszruty w sieci torowej odbywa się tylko przed rozjazdem na odcinku trasy wyposażonym w dwie szyny, jak pokazano na rys. 2. Dostatecznie długi odcinek dwuszynowy toru powinien znajdować się przed każdym rozjazdem oraz w obrębie samego rozjazdu.

Na rys. 4a przedstawiono wagonik pod estakadą w obrębie wejścia w rozjazd na wybranym kierunku „w lewo". Przed wejściem w rozjazd, trakcyjne rolki nośne $\underline{5}$ wagonika, które w torze pozbawionym rozjazdów współpracowały z nitką 
toru prostego, zostały uniesione, zaś cała masa spoczęła w torze na rolkach $\underline{4}$ biegnących po nitce 2 toru biegnącej „w lewo”. W ten sposób wagonik pobiegnie wzdłuż nitki toru „w lewo”. Podobnie na rys. 4b zilustrowano wejście wagonika w rozjazd na wybranym kierunku „w prawo”. Rolki górne są unoszone wraz z całym wagonikiem $\underline{\mathrm{W}}$. Pasażerowie nie odczuwają powolnego ruchu unoszenia wagonika. Zasadę wyboru toru w obrębie rozjazdu pokazano na rys.5.

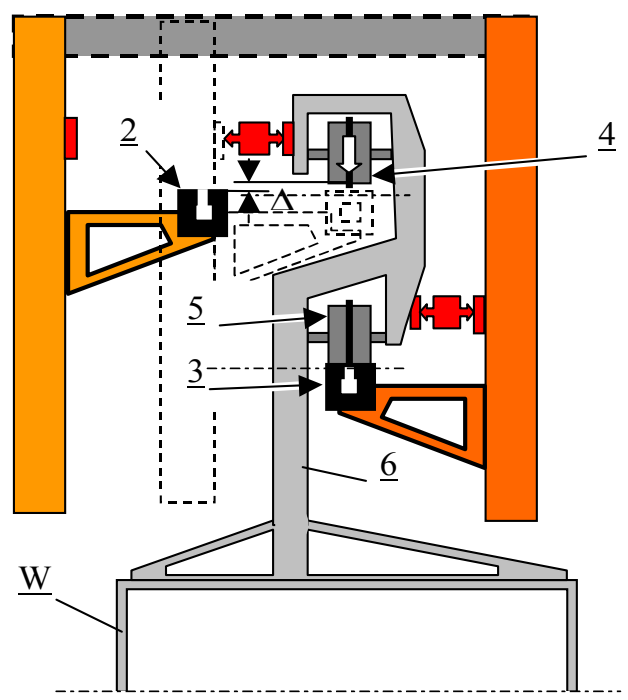

Rys.5. Zasada wyboru toru z pokładu wagonika w obrębie rozjazdu

\section{Ogólne założenia budowy systemu}

- System torowy estakadowy, z wagonikami podwieszonymi

- Sieć estakadowa w ogólnie pojmowanym układzie 'pajeczyny'

- Infrastruktura całkowicie bierna; rozjazdy estakadowe bez jakichkolwiek części ruchomych

- Programowanie trasy przejazdu z wnętrza wagonika przez podanie jedynie punktu docelowego na 'pajęczynie'

- Wagoniki napędzane elektrycznie, ok. 4-osobowe, z systemem głosowego powiadamiania podróżnych

- Wszystkie przetworniki mocy, układy sterowania napędu trakcyjnego oraz zautomatyzowanego wyboru trasy przejazdu znajdują się w wagonikach

- Odległości minimalne pomiędzy wagonikami sterowane automatycznie

- W przypadku zaniku napięcia samoczynnie uruchamia się hamulec cierny

- Wagonik wyposażony w awaryjny system komunikacji z dyspozytorem

- Możliwość zastosowania linowej wciagarki dla awaryjnego opuszczania 'kapsuły' wagonika z pasażerami na linach $\mathrm{z}$ estakady na poziom ulicy.

\section{Wymagania techniczno-ruchowe dla wagonika}

- Prędkość przewozowa (od punktu początkowego do celu) ok. $40 \mathrm{~km} / \mathrm{h}$

- Masa własna wagonika nie powinna przekraczać $1000 \mathrm{~kg}$

- Moc startowa wagonika nie powinna przekraczać $50 \mathrm{~kW}$

- Adhezyjne przeniesienie sił napędowych i hamujących na tor

- Wzniesienie / spadek toru nie większy niż 10\%

- Należy zapewnić możliwość indukcyjnego wywiązywania sił trakcyjnych i hamujących w przyszłości

- Należy rozważyć możliwość zastosowania napędu zębatkowego na spadkach / wzniesieniach większych niż 20\%

- Należy uwzględnić możliwość zastosowania rolek bocznych poprzecznie stabilizujących wagonik w warunkach silnego wiatru bocznego.

\section{Techniczne parametry wspólpracy wagonika $z$ belką torową $z$ punktu widzenia ergonomii}

Rozsądek gospodarczy nakazuje możliwie rzadkie rozmieszczanie podpór torowych. Belka torowa pomiędzy podporami będzie ulegała ugięciom pod działaniem sił grawitacyjnych, pochodzących od masy własnej oraz od wagonika (rys.6). W punkcie B dopuszcza się zaburzenie pionowego przyśpieszenia o wartości nie większej niż 0,1g.

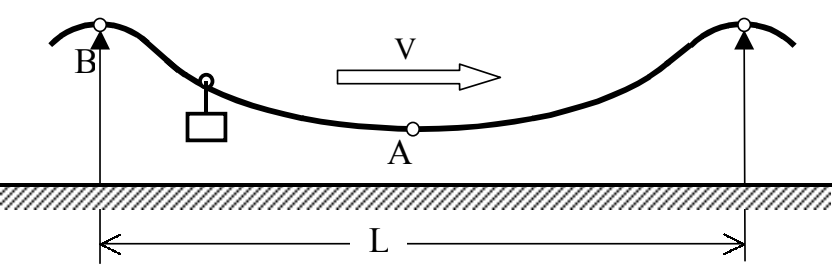

Rys. 6. Przybliżona linia ugięcia belki torowej

Odwzorowanie (z technicznym przybliżeniem) odwróconej linii ugięcia belki torowej może stanowić ogólnie pojmowana cykloida skrócona (trochoida), pokazana na rys. 7 .

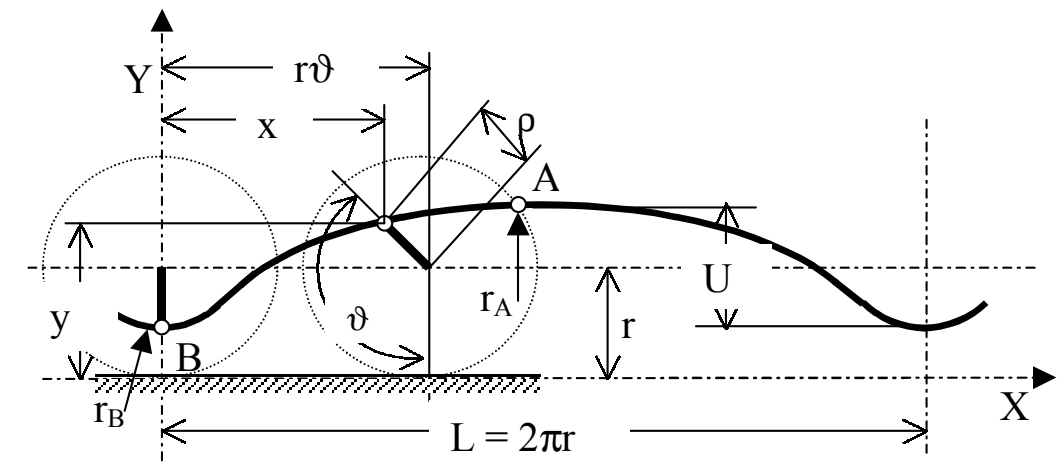

Rys.7. Aproksymacja odwróconej linii ugięcia belki torowej (cykloidy skróconej) 


\section{Oznaczenia:}

L- rozstaw podpór torowych

$\mathrm{V}$ - prędkość jazdy wagonika

$\mathrm{U}$ - maksymalne (wypadkowe) ugięcie toru pod wagonikiem

$\mathrm{t}$ - czas (zmienna niezależna)

$\mathrm{T}$ - okres trochoidy

$\omega$ - prędkość kątowa koła trochoidy

$\Omega$ - prędkość kątowa koła wagonika

$\mathrm{r}$ - promień okręgu koła trochoidy

$\mathrm{R}$ - promień okręgu tocznego koła wagonika

$\rho$ - promień korby trochoidy

$\vartheta$ - bieżąca wartość kąta obrotu ramienia korby

$\lambda$ - współczynnik wykorbienia trochoidy

Podstawowe wzory są następujące:

$\rho=\frac{U}{2} ; \quad \rho=\lambda r ; \quad r=\frac{L}{2 \pi} ; \quad \vartheta=\omega t ; \quad t=\frac{x}{V}$

$$
\left.\begin{array}{c}
\mathrm{L}=2 \pi r \\
L=\omega r T=V T \\
\omega=\frac{V}{r}=\frac{2 \pi V}{L}
\end{array}\right\}
$$

Równanie parametryczne cykloidy skróconej (trochoidy):

$$
\left.\begin{array}{l}
x=r \vartheta-\rho \sin \vartheta=r(\vartheta-\lambda \sin \vartheta) \\
y=r-\rho \cos \vartheta=r(1-\lambda \cos \vartheta)
\end{array}\right\}
$$

\{ Przejście graniczne: gdy $\lambda=0$, to także $\rho=0$; wtedy otrzymuje się równanie ruchu środka abstrakcyjnego „koła trochoidy”, toczącego się bez poślizgów po sztywnym podłożu:

$$
x=r \omega t ; \quad y=r=\text { const }\}
$$

Promień rzeczywistego koła wagonika nie ma nic wspólnego z promieniem abstrakcyjnego koła trochoidy. Sa jednak ściśle określone kinematyczne więzy pomiędzy tymi kołami:

$$
\left.\begin{array}{l}
x=r \omega t=R \Omega t \\
\text { oraz } \\
L=r \omega T=R \Omega T
\end{array}\right\}
$$

(Zatem $r \omega=R \Omega$ )

Wielkości zadane (narzucone), to L oraz $\mathrm{V}$, zaś wielkości mierzone to $\mathrm{U}$ oraz t. Znając więzy kinematyczne (4), przyjmując wielkości narzucone (2) oraz mierząc U i t, dokonuje się pełnej identyfikacji parametrów trochoidy wg (5):

$$
\rho=\frac{U}{2} ; \quad r=\frac{L}{2 \pi} ; \quad \lambda=\frac{\rho}{r} ; \quad \omega=\frac{V}{r} ; \quad t=\frac{x}{V} ; \quad \vartheta=\omega t ;
$$

Zależności (5) wynikają wprost z równań (1) i (3).

Promienie krzywizn dla maksimum w pkt. A trochoidy, oraz dla minimum $\mathrm{w}$ pkt. B, wynoszą odpowiednio:

$$
\left.\begin{array}{l}
r_{A}=\frac{-r(1+\lambda)^{2}}{\lambda} \\
r_{B}=\frac{r(1-\lambda)^{2}}{\lambda}
\end{array}\right\}
$$

Podpory są umieszczone w punktach odpowiadających minimum trochoidy.

Ze względu na czynniki ergonomiczne, przyśpieszenie wagonika $w$ obrębie punktu $B$ nie powinno przekraczać $\mathbf{0 , 1 g}$; zatem można napisać:

$$
\frac{V^{2}}{r_{B}} \leq 0,1 g \quad c z y l i \quad \frac{V^{2} \lambda}{r(1-\lambda)^{2}} \leq 1\left[\frac{m}{s^{2}}\right]
$$

albo (tylko w jednostkach SI), przy podstawieniu $0,1 \mathrm{~g} \approx 1\left[\mathrm{~m} / \mathrm{s}^{2}\right]$

$$
V^{2} \leq \frac{L^{2}}{2 \pi^{2} U}\left(1-\frac{\pi U}{L}\right) ;\left[\frac{m}{s}\right]^{2}
$$

Wzór (7), w którym fizyczne jednostki przyśpieszenia są niejawne, stanowi 'ergonomiczny' warunek właściwego doboru parametrów belki torowej $\mathrm{L} / \mathrm{U}$, gdy wagoniki nie mają pionowego usprężynowania.

8. Zasady sterowania wagonika $w$ rozjazdach i na przystankach oraz zarządzania siecią transportową Przykładowy schemat przystanku pokazano na rys.8. 


\subsection{Podstawowe zasady sterowania wagonika}

- Tor ma dwie szyny, górną i dolną. Na schemacie: kolorem czerwonym oznaczono tok szynowy górny; niebieskim - tok szynowy dolny

- Szyna górna określa podstawowy tor ruchu wagonika

- Tor ruchu i szyna zasilania prądowego są odpowiednio skorelowane tak, aby wagonik był stale zasilany w energię elektryczną

- Na podstawowym kierunku ruchu wagonika pracują trakcyjnie tylko górne rolki biegowe

- Zejście z podstawowego kierunku ruchu możliwe jest tylko w rozjeździe

- Dla zmiany kierunku ruchu w obrębie rozjazdów niezbędne jest krótkotrwałe przełączanie górnych rolek biegowych wagonika na dolne

- Szyna dolna określa zmieniony tor ruchu wagonika w rozjeździe i tuż za rozjazdem

- W określonej odległości za rozjazdem przywracany jest bieg oraz napęd wagonika na szynie górnej; w ten sposób zostaje 'zresetowany' podstawowy tor ruchu

- Przełączanie rolek biegowych jest odpowiednio skojarzone z samoczynnym przełączaniem aktywnego napędu trakcyjnego
- Załączanie górnych lub dolnych silników trakcyjnych jest sterowane sygnałem ciśnienia oleju w siłowniku opuszczania i podnoszenia dolnych rolek biegowych

- Pokładowy system sterowania wagonika jest autonomiczny. Reaguje on na dwa rodzaje sygnałów: pokładowy (wewnętrzny) i sieciowy (zewnętrzny).

$\rightarrow$ Sygnal „pokladowy” (wewnętrzny) stanowi informację o wybranym przez pasażera (jednoznacznie zdeterminowanym) docelowym punkcie podróży. Wybór 'optymalnej' trasy obciążonego wagonika jest dokonywany przez komputer pokładowy. Sygnał pokładowy jest przekazywany do dyspozytorni.

$\rightarrow$ Sygnal „sieciowy” jest (odpowiednio wczesnym, cyfrowym) rozkazem odjazdu wagonika pustego ( $\mathrm{z}$ przystanku) do jednego $\mathrm{z}$ sąsiednich przystanków w sieci, w celu ustąpienia miejsca dla wagonika aktualnie zmierzającego do tego przystanku docelowego (wybranego przez pasażera na początku trasy). Sygnały sieciowe służą też jako rozkazy uzupełnienia niezbędnego zapasu wagoników na przystankach. Sygnały sieciowe sa przekazywane bezstykowo.

$\rightarrow$ Sygnal odległości między wagonikami (pustymi oraz obciążonymi) jest dla wagonika sygnałem sieciowym zewnętrznym niezdeterminowanym.

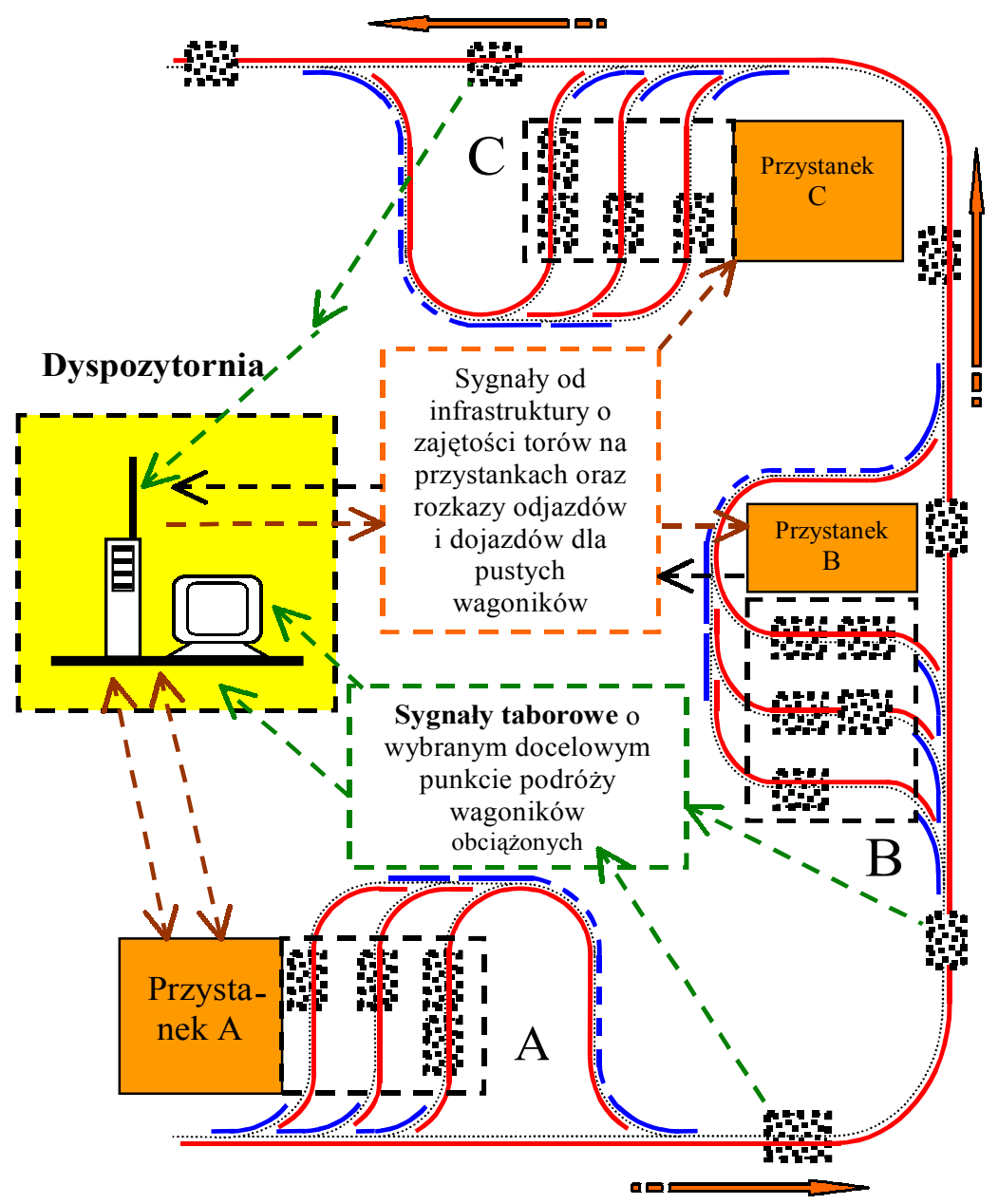

\subsection{Ogólne zasady zarządzania sie- cią transportową}

$\mathrm{Na}$ rys.9 pokazano schematycznie fragment estakadowej sieci transportowej.

Rys.9. Fragment estakadowej sieci transportowej i zasada zarządzania 
- System transportowy w sieci torów jest zaprojektowany tak, że cały tabor może równocześnie swobodnie zmieścić się na postoju w obrębie przystanków. Na każdym przystanku powinna znajdować się niezbędna liczba wagoników. Zagadnienie systemowej redundancji stanowi wydzielony problem naukowy.

- Sieciowy system komputerowego sterowania wagonikami składa się z części czynnej i biernej. System sieciowy gromadzi i odpowiednio przetwarza sygnały (pochodzące $\mathrm{z}$ infrastruktury) o aktualnym stanie zajętości poszczególnych przystanków oraz wszystkie sygnały taborowe o wybranych przystankach docelowych i o zbliżaniu się

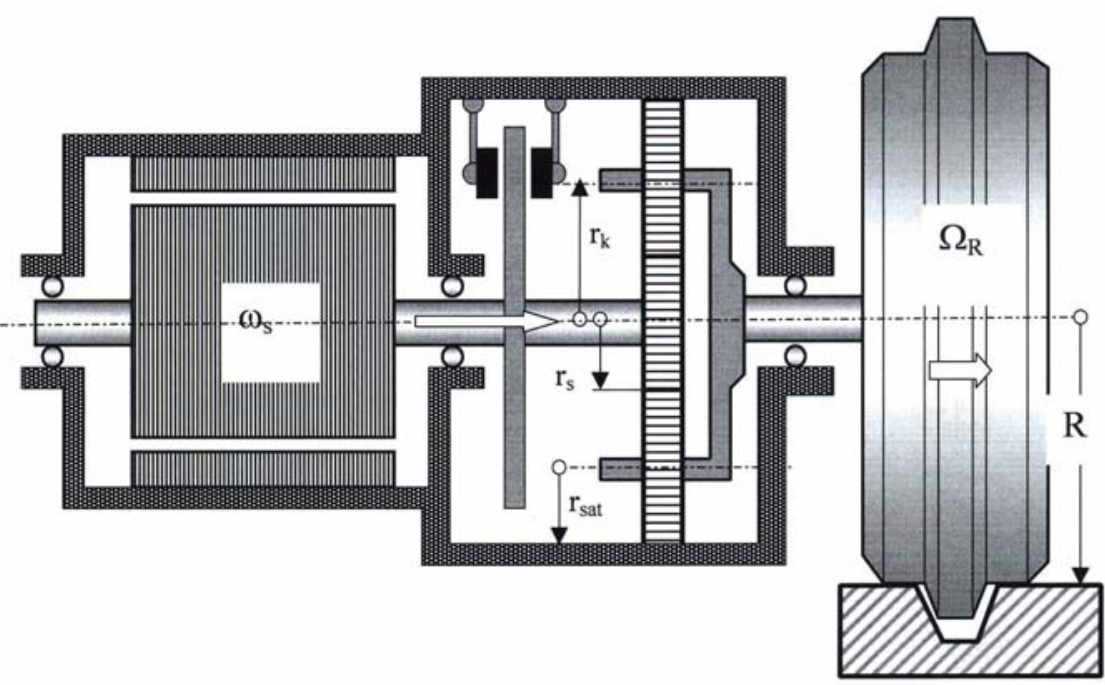

Rys.10. Schemat przekładni mechanicznej z samoczynnym hamulcem sprężynowo - luzownikowym i jej charakterystyczne parametry każdego wagonika do wybranego przystanku (z należytym wyprzedzeniem czasowym). Sterowanie siecia jest rozczłonkowane na sterowanie poszczególnymi przystankami.

$\rightarrow$ Część bierna sieciowego systemu sterowania dostarcza do wagonika sygnał o zbliżaniu się do zidentyfikowanego rozjazdu dla odpowiedniego przesterowania kierunku jazdy na trasie wybranej przez komputer pokładowy. W praktyce sygnał ten pochodzi z pokładowego czujnika położenia wagonika na trasie odpowiednio oznakowanej (obowiązkowo przed rozjazdami).

$\rightarrow$ Część czynna (aktywna) sieciowego systemu sterowania zarządza ruchem wagoników pustych tak, aby każdy zbliżający się wagonik z pasażerami mógł w odpowiednim czasie znaleźć miejsce na przystanku wybranym przez pasażera na początku podróży. Część aktywna sieciowego systemu sterowania wagonika przekazuje do wagonika sygnał o numerze toru parkingowego. Część aktywna sieciowego systemu sterowania (z wyjątkiem sytuacji awaryjnych) nie powinna mieć wpływu na 'optymalny’ wybór trasy wagoników w sieci torów estakadowych.

Kontroler wagonika reaguje na wewnętrzny sygnał wyboru celu podróży, oraz sygnały zewnętrzne:

- położenia w sieci torowej (zbliżanie się do określonego rozjazdu)

- rozkaz opuszczenia przystanku

- numer toru parkingowego na przystanku docelowym; kontroler wagonika steruje też płynnością trakcyjnego procesu rozruchu i hamowania.

\section{Przekładnia mechaniczna układu napędowego wagonika (rys.10)}

Przełożenie przekładni $\mathrm{i}=\omega_{\mathrm{S}} / \Omega_{\mathrm{R}}$ :

$$
i=\frac{2\left(r_{s}+r_{s a t}\right)}{r_{s}} ; \quad r_{s a t}=\left(\frac{i}{2}-1\right) r_{s}
$$

gdzie:

$\mathrm{r}_{\mathrm{k}}$ - promień okręgu osadzenia osi satelitów koszu

$\mathrm{r}_{\mathrm{s}}$ - promień podziałowy koła słonecznego przekładni planetarnej

$\mathrm{r}_{\text {sat }}$ - promień podziałowy koła satelitarnego przekładni planetarnej

$\mathrm{R}$ - promień trakcyjny rolki biegowej (koła biegowego) wagonika

$\omega_{\mathrm{s}}$ - prędkość obrotowa wirnika trakcyjnego silnika elektrycznego

$\Omega_{R}$ - prędkość obrotowa rolki trakcyjnej wagonika

\section{Podsumowanie}

Przedstawiony oryginalny system podwieszonej pasażerskiej kolejki estakadowej został zgłoszony do opatentowania [1].

Glówną praktyczną korzyścią zaprezentowanego rozwiązania jest całkowita eliminacja przestawnych, ruchomych części infrastruktury torowej (także w obrębie rozjazdów), przy równoczesnym umożliwieniu automatycznego sterowania marszruty z pokładu wagonika (przejazdu po wybranej trasie w obszarze określonej sieci „rozjazdów” torowych).

Omówiono najistotniejsze zagadnienia dotyczące dwóch nierozdzielnych, wzajemnie technicznie zależnych składników systemu: infrastruktury i pojazdów. Infrastruktura składa się z toru estakadowego wyposażonego w oryginalne nieruchome rozjazdy i klasyczne zasilające szyny energetyczne. Podwieszone wagoniki są wyposażone w pantografy, specjalne podwozia i elektrycznie napędzane koła. 
Docelowy punkt podróży w obrębie znanej sieci torów (rozumianej jako zespół dostępnych trajektorii transportowych) jest sygnalizowany przez pasażera na pokładzie wagonika. Wybór i sterowanie trasy (marszruty) przejazdu wagonika w obrębie określonej sieci torowej jest dokonywany automatycznie przez odpowiednio oprogramowany komputer pokładowy wagonika wyposażonego $\mathrm{w}$ indywidualny układ napędowy. Obciążeniem poszczególnych przystanków i ruchem wagoników pustych steruje bezprzewodowo centralny komputer stacjonarny.

\section{LITERATURA}

[1] Madej J., Choromański Wt.: Uktad biegowy kolejki estakadowej. Zgloszenie patentowe, Politechnika Warszawska, Zespót Rzeczników Patentowych. Nr zgtoszenia P. 381106 wg pisma ZRPat /3825/2006 z dnia 15. 12. 2006 